\title{
Cooperative Federalism and Constructive Waiver of State Sovereign Immunity
}

\author{
Sarah C. Rispin $\dagger$
}

In drafting cooperative federalism statutes, which rely on state government bodies to design and implement local regulation according to national standards,' Congress has generally provided for private suits against state regulators to ensure that the states properly carry out the regulatory tasks they undertake on Congress's behalf.' The strengthening of the state sovereign immunity doctrine, a prominent aspect of the Rehnquist Court's federalism revival," has thrown several hurdles in the way of private litigation against states under these statutes.

Congress may no longer directly abrogate states' sovereign immunity through statutes passed pursuant to its Article I powers; the Court sees this as necessary to avert the dignitary harm to the states of being hauled into court by private attorneys general. ${ }^{4}$ As a result, most suits that proceed against the states under cooperative federalism statutes do so under the Ex Parte Young fiction, which allows plaintiffs to sue state officials for prospective relief for ongoing violations of federal law. This route, however, is less effective than it once was."

Additionally, Congress may still authorize private litigation against the states through a constructive waiver of their sovereign immunity - the subject of this Comment. While the Supreme Court has substantially narrowed the constructive waiver exception to prevent Congress from using it to make an end-run around the abrogation ban, it has not, as some have urged, written it out of the law. Con-

$\dagger$ B.A. 1996, Williams College: J.D. 2003, The University of Chicago.

See text accompanying note 15 .

See Part I.B.

3 See Richard H. Fallon, Jr., The "Conservative" Paths of the Rehnquist Court's Federalism Decisions, 69 U Chi L Rev 429,429-30 (2002) (noting that since 1991 "the Court has maintained a relatively stable five-justice majority ... committed to enforcing limits on national power and to protecting the integrity of the states" that "[c]ommentators unhesitatingly refer to [as] a federalism 'revival"').

4 With the exception of legislation passed pursuant to the Fourteenth Amendment. See Part II.A.

5 See generally Ex Parte Young, 209 US 123 (1908).

6 Two recent Supreme Court opinions have rendered Ex Parte Young suits difficult and uncertain. See Idaho v Coeur d'Alene Tribe of Idaho, 521 US 261 (1997); Seminole Tribe v Florida, 517 US 44 (1996). For a full discussion of these cases, see Part II.A.

7 See College Savings Bank v Florida Prepaid Postsecondary Education Expense Board. 
structive waiver may still be obtained from a state as long as it is voluntarily exchanged for some sort of "gratuity" from the federal government. Because the Supreme Court has only accepted one somewhat obscure incidence of constructive waiver, few plaintiffs have attempted to use this theory for suits brought under cooperative federalism statutes.

In the past few years, a series of circuit court cases under the 1996 Telecommunications Act (Telecom Act) ${ }^{4}$ established a new category of constructive waiver-which I shall call "regulation as waiver" -allowing Congress to render states amenable to suit in their role as regulators under cooperative federalism schemes. Under the theory advanced in these cases, Congress can obtain a constructive (as opposed to explicit) waiver from the states by granting them the gratuity of the opportunity to participate in regulatory activity that would otherwise be foreclosed to them by federal occupation of the field. ${ }^{10}$ In other words, states will be presumed to have constructively waived their sovereign immunity by agreeing to participate as regulators in cooperative federalism regulatory schemes, where the federal statute makes it clear that the state will be subject to suit in federal court for its actions as regulator. This is a positive doctrinal development from the policy-design perspective, as Congress can ensure when it invites the states to act alongside it as regulators that states are as accountable as the federal government for how they carry out that regulation.

The regulation as waiver theory's validity remains open to question in the federal courts. Although the Fifth, Seventh, and Tenth Circuits have accepted the theory," the Fourth and Sixth Circuits have rejected it. ${ }^{12}$ The Supreme Court agreed to address the theory's validity

527 US 666, 675-87 (1999).

8 See Part II.B (discussing implications of College Savings Bank on the constructive waiver doctrine).

9 Telecommunications Act of 1996, Pub L No 104-104, 110 Stat 56 (1996), codified in various sections of 47 USC (2000). The language at issue is contained in 47 USC $\$ \$ 251-52$ (2000).

10) See AT\&T Communications v BellSouth Telecommunications, 238 F3d 636, 645-46 (5th Cir 2001) (stating that Congress can obtain a non-verbal regulatory waiver); $M C I$ Telecommunications Corp v Illinois Bell Telephone Co, 222 F3d 323, 342 (7th Cir 2000), cert denied, 531 US 1132 (2001) (finding that states voluntarily waive their sovereign immunity by accepting the "invitation to act as regulators of the local telephone market"); $M C I$ Telecommunications Corp v Public Service Commission of Utah, 216 F3d 929, 938 (10th Cir 2000), cert denied, 531 US 1183 (2001) (finding that Congress clearly "condition[ed] a state's ability to regulate local phone service," a gratuity, on the state's "consent to suit in federal court").

11 See note 10.

12 See Bell Atlantic Maryland v MCI Worldcom, 240 F3d 279, 309 (4th Cir 2001) (concluding that state participation in the regulation of interconnection agreements did not result in a waiver of sovereign immunity); Michigan Bell $v$ Climax Telephone, 202 F3d 862, 867 n 2 (6th Cir 2000) (peremptorily rejecting the regulation as waiver theory). See also Stephanie Chapman, Note, MCI Telecommunications Corp. v. Public Service Commission: The Tenth Circuit Rebuffs the Supreme Court Trend Supporting State Immunity, 55 Okla L Rev 175 (2002) (criticizing regu- 
in a recent case concerning the Telecom Act, but ultimately ruled that the suit could go forward under Ex Parte Young."

Now that the Supreme Court has given its blessing to Ex Parte Young suits under the Telecom Act, private litigants subject to the Act should generally be expected to proceed by that route. However, the regulation as waiver theory has potentially interesting implications for plaintiffs pursuing private litigation against the states under cooperative federalism statutes in general. While private plaintiffs may technically proceed under the Ex Parte Young theory, states are aggressively asserting various new exceptions to the doctrine, rendering whether Ex Parte Young creates an exception to state sovereign immunity in the context of a particular statute or for a particular plaintiff a focus of litigation in every one of these suits.

This Comment argues that regulation as waiver at once provides a viable alternative route for private litigation under cooperative federalism statutes, and comports well with current state sovereign immunity doctrine. Part I of this Comment introduces the cooperative federalism model, and the importance of private litigation to this model. Part II sketches out the limitations that the Supreme Court's current state sovereign immunity jurisprudence places on private litigation under cooperative federalism schemes, presents the regulation as waiver theory, and discusses how it has been received in the courts. Finally, Part III argues that regulation as waiver not only clearly fits within the bounds of the Court's constructive waiver doctrine, but also helps promote the larger goals of the federalism revival. Unless the scope of Congress's regulatory powers is curtailed more sharply than it has been, the reality will remain that Congress possesses and uses the ability to regulate almost every corner of American economic life. The cooperative federalism model carves out a significant role for the states in the regulation of many of those areas. Insofar as the availability of regulation as waiver preserves cooperative federalism as an attractive regulatory model for Congress, without violating the impera-

lation as waiver as barred by a recent Supreme Court opinion on constructive waiver); Recent Cases: Seventh Circuit Holds That States Waive Sovereign Immunity by Arbitrating Interconnection Agreements under the Telecommunications Act of 1996, 114 Harv L Rev 1819 (2001) (same).

13 See Mathias $v$ Worldcom Technologies, 532 US 903 (2001), cert dismissed as improvidently granted, 535 US 682 (2002), and subsequently denied as Illinois Bell v WorldCom, 535 US 1107 (2002) (certifying "[w]hether a state commission's acceptance of Congress' invitation to participate in implementing a federal regulatory scheme that provides that state commission determinations are reviewable in federal court constitutes a waiver of Eleventh Amendment immunity"). But see Verizon v Public Service Commission of Maryland, 535 US 635, 645 (2002) (determining that "[w]hether the Commission waived its immunity is [a] question we need not decide, because ... even absent waiver, [plaintiff] may proceed against the individual commissioners in their official capacities, pursuant to the doctrine of Ex Parte Young"). 
tive that states give up their immunity voluntarily, advocates of a robust system of dual sovereignty should cheer.

\section{CoOperative FEDERALISM}

Under the Supremacy Clause of the United States Constitution," when enacting regulation pursuant to any of its enumerated powers, Congress may completely displace state regulation and implement a purely federal regulatory scheme. However, in a variety of fields, it may see an advantage to regulating in partnership with local governments, and would therefore turn to the cooperative federalism model, carving out a role for state bodies in areas governed by preemptive federal regulation. Congress generally includes provisions authorizing private suit against state regulators in these statutes to ensure their enforcement.

\section{A. Cooperative Federalism Statutes}

As defined by the Supreme Court, cooperative federalism statutes are federal laws adopted pursuant to Congress's "authority to regulate private activity under the Commerce Clause," that "offer States the choice of regulating that activity according to federal standards or having state law pre-empted by federal regulation."'s Starting with the passage of several major environmental statutes ${ }^{16}$ in the 1970 s, Congress has "repeatedly endorsed the cooperative federalism strategy." More diverse cooperative federalism regulatory schemes include: Medicaid," the Occupational Safety and Health Act," the Public

14 US Const Art VI ("This Constitution, and the Laws of the United States which shall be made in Pursuance thereof ... shall be the supreme Law of the Land.").

15 New York v United States, 505 US 144, 167 (1992).

16 These include the Air Pollution Prevention and Control Act (also known as the Clean Air Act), Pub L No 91-604, 84 Stat 1676 (1970), codified at 42 USC $\$ 7401$ et seq (2000); the Federal Water Pollution Prevention and Control Act (also known as the Clean Water Act), Pub L No 92-500, 86 Stat 816 (1972), codified at 33 USC $\$ 1251$ et seq (2000); the Solid Waste Disposal Act, Pub L No 89-272, 79 Stat 997 (1965), as amended by the Resource Conservation and Recovery Act, Pub L No 94-580, 90 Stat 2795 (1976), codified at 42 USC $\$ 6901$ et seq (2000); and the Surface Mining Control and Reclamation Act, Pub L No 95-87.91 Stat 445 (1977), codified at 30 USC $\$ 1201$ et seq (2000).

17 Philip J. Weiser, Federal Common Law, Cooperative Federalism, and the Enforcement of the Telecom Act, 76 NYU L Rev 1692, 1694 (2001).

18 Title XIX of the Social Security Act. Pub L No 103-66, 107 Stat 624 (1965), codified at 42 USC $\S 1396$ et seq (2000) (granting medical assistance funds to states, conditioned on approval of state plans).

19 Pub L No 91-596, 84 Stat 1590 (1970), codified at 29 USC $\$ 651$ et seq (2000). See 29 USC $\$ 667$ (b) (giving states the option of preempting federal regulation if they "assume responsibility for development and enforcement" of occupational health and safety). 
Utility Regulatory Policies Act, ${ }^{211}$ the Adoption Assistance and Child Welfare Act, ${ }^{21}$ and the Cable Communications Policy Act. ${ }^{22}$

These statutes rely on local government bodies to design and implement local regulation according to national standards. The Clean Air Act, for example, sets national ambient air quality standards, ${ }^{23}$ but charges the states with achieving them through state implementation plans designed by the states and approved by the Environmental Protection Agency (EPA). ${ }^{24}$ The Telecom Act, which mandates that local telephone monopolies enter into interconnection agreements with would-be competitors, ${ }^{25}$ invests state commissions with primary responsibility for enforcing those interconnection agreements. ${ }^{26}$ By having the local government bodies implement federal regulation locally, these statutes preserve a role for the states in areas that the federal political branches have decided it is in the nation's best interest to regulate according to a central design.

\section{B. The Role of Private Litigation in Cooperative Federalism}

Cooperative federalism statutes generally provide private citizens with a right of action to sue both federal and state regulatory bodies responsible for their implementation. Congress's express purpose in making these provisions is to vindicate the rights of the regulated community that may be impinged upon in the course of regulation, and to make sure that the states hold up their end of the regulatory bargain. This mirrors the system through which the federal government makes itself accountable under purely federal regulatory schemes.

\section{Rights-vindicating provisions.}

As the growth of the administrative state brought more and more activity within the ambit of federal regulation, the federal government

20) Pub L No 95-617, 92 Stat 3117 (1978), codified at 16 USC $\$ 2601$ et seq (2000). See 16 USC $\$ 824 a-3(f)$ (requiring states to implement standards promulgated by the Federal Energy Regulatory Commission).

21 Pub L No 96-272, 94 Stat 500 (1980), codified at 42 USC $\$ 675$ (2000).

22 Pub L No 98-549. 98 Stat 2779 (1984), codified at 47 USC $\$ \$ 571-73$ (2000).

2342 USC $\$ 7409$.

24 Id $\$ 7410(a)$.

2547 USC $\$ 251$ (c)(1) (requiring incumbent telecommunications service providers to negotiate interconnection agreements with new entrants in good faith).

26 See generally id $\$ 251$. If private negotiation of an interconnection agreement fails, either party can petition the state commission that regulates local phone service to arbitrate. See id $\$ 252$ (b)(1). Once an agreement is concluded-by either negotiation or arbitration-it must be submitted for approval to the state commission, which may reject the agreement if it does not comply with Section 251 of the Act. Id $\$ 252(\mathrm{e})(1)-(2)$. 
made itself amenable to suit under the Administrative Procedure $\mathrm{Act}^{27}$ and various individual regulatory statutes ${ }^{2 k}$ to prevent federal regulators from abusing their powers at the regulated community's expense. ${ }^{29}$ When Congress began to use the cooperative federalism model, it naturally provided causes of action in cooperative federalism statutes against both federal and state agencies. This ensures the same kind of accountability, regardless of whether a state or federal agency happened to be carrying out a certain portion of the federal regulation. The section of the Telecom Act governing interconnection agreements, for instance, provides that "in any case in which a State commission makes a determination under this section, any party aggrieved by such determination may bring an action in an appropriate Federal district court to determine whether the agreement or statement meets the requirements" of the Act. ${ }^{3 \prime \prime}$

\section{Citizen suit provisions.}

Standing to sue under most federal regulatory statutes does not end with the regulated community. In the past thirty years, Congress has also included citizen suit provisions in a wide range of federal regulatory statutes, granting private citizens the right to sue administrators for failing to enforce the laws as Congress requires." While there is some controversy about the efficacy of citizen suits in addressing the problem of federal agency inaction, ${ }^{32}$ the idea is that the threat

275 USC $\$ 551$ et seq $(2000)$. Section 10 of the Act, codified at 5 USC $\$ \$ 701-06$, provides for judicial review at the bchest of parties that suffer legal wrong due to final agency action.

28 Many statutes give aggrieved parties the right to seek judicial review of agency actions in federal court. See, for example. National Labor Relations Act, 29 USC $\$ 160$ (f) (2000) (providing that final orders of the National Labor Relations Board may be reviewed in federal courts of appeals); Social Security Act $\$ 205(\mathrm{~g}), 42$ USC $\$ 405(\mathrm{~g})$ (2000) (providing for federal district court review of final and adverse administrative decisions on social security claims). Others render agency actions binding only when the agency brings an enforcement action in federal court, at which point adversely affected parties may contest the actions. See, for example, Interstate Commerce Commission Termination Act, 49 USC $\$ 11705$ (c)-(d) (2000) (orders of the Interstate Commerce Commission); Packers and Stockyards Act $\$ 309(\mathrm{f}), 7$ USC $\$ \$ 210(\mathrm{f}), 499 \mathrm{~g}(\mathrm{~b})$ (2000) (selected orders of the Department of Agriculture).

29 See, for example, National Wildlife Federation v United States, 626 F2d 917, 918 n 1, 923 (DC Cir 1980) (stating that federal courts have the power to command federal officers to fulfill their obligations).

3) 47 USC $\$ 252(e)(6)$.

31 See Cass R. Sunstein, What's Standing after Lujan? Of Citizen Suits, "Injuries," and Article III, 91 Mich L Rev 163, 165 n 11 (1992) (listing "the large number of statutes" in which Congress used the citizen suit "as a mechanism for controlling unlawfully inadequate enforcement of the law"). See also id at 192-93.

32 See, for example, Frank B. Cross, Pragmatic Pathologies of Judicial Review of Administrative Rulemaking, 78 NC L Rev 1013, 1023 (2000) ("When a regulator must anticipate and adapt to every conceivable challenge and the reaction of the most hostile judge, she is destined to spend most of her time 'playing defense' with little time left for taking regulatory affirmative action."). 
of citizen suits will motivate regulators to carry out their mandates and take action against violators.

Citizen suit provisions figure prominently in most cooperative federalism statutes. ${ }^{33}$ Again, they are intended as a guarantee that regulation - whether by federal or state agencies-will occur as promised, and that the statutes will be rigorously enforced. The Clean Air Act's citizen suit provision, for example, "reflected a deliberate choice by Congress to widen citizen access to the courts, as a supplemental and effective assurance that the Act would be implemented and enforced. ${ }^{\text {,4 }}$

In an ideal world, citizen suits would not be necessary for enforcement: The federal or state agency charged with implementing a federal regulation would carry out its mandate in accordance with the law. But agencies may become overloaded or bogged down in bureaucratic inertia. More insidiously, they may implicitly or explicitly bend to interest group pressure that discourages them from carrying out their regulatory tasks. As one commentator has noted: "Theoretically, the governments adopting the standards should enforce them, but in practice governments and their regulatory agencies often come to identify with the industries or companies they regulate. ${ }^{, 35}$ At the state level, danger of interest group capture can be particularly acute, leading to no or nominal regulation. ${ }^{36}$ At the same time, federal agencies

33 In the Clean Air Act, for example, Congress included a citizen suit provision which provides that any person may bring suit against the federal government or "any other governmental instrumentality or agency" that fails to properly implement the aspect of the Act with which it is charged. See 42 USC $\$ 7604$ (a) (providing that any person may "commence a civil action on his own behalf - (1) against any person (including (i) the United States, and (ii) any other governmental instrumentality or agency) ... who is alleged to have violated ... or to be in violation of .. . an emission standard or limitation under this chapter"). Failure to implement a state implementation plan (SIP) or revisions of a SIP without EPA approval are considered "violations," for which the state regulator can be held accountable. See, for example, Sweat $v$ Hull, 200 F Supp $2 \mathrm{~d}$ 1162,1171 (D Ariz 2001) ("[T]he Court finds, as a matter of law, that the repeal of the RSD Program, and in turn Arizona's subsequent non-enforcement of the EPA-approved SIP, constituted a violation of federal law."), citing 42 USC $\$ 7416$.

34 Natural Resource Defense Council, Inc v Train, 510 F2d 692, 700 (DC Cir 1975), citing National Air Quality Standards Act of 1970, S Rep No 1196, 91st Cong, 2d Sess 64 (1970), reprinted in Environmental Policy Division of the Congressional Research Service, 1 A Legislative History of the Clean Air Amendments of 1970464 (GPO 1974); Baughman v Bradford Coal Co, 592 F2d 215, 218 (3d Cir 1979) (noting that Congress intended the citizen suit provision in the Clean Air Act to enable citizens to "goad[] responsible agencies to more vigorous enforcement of the anti-pollution standards"); Friends of the Earth v Carey, 535 F2d 165, 173 (2d Cir 1976) ("[T]he very purpose of the citizens' liberal right of action is to stir slumbering agencies.").

35 Richard L. Ottinger, Renewable Energy Sources for Development, 32 Envir L 331, 352 (2002).

36 See Pamela H. Bucy, Private Justice, 76 S Cal L Rev 1, 33 (2002) ("Apparently some states routinely collude with polluters by issuing token compliance orders solely to preempt citizen suits."); Susan George, William J. Snape III, and Rina Rodriguez, The Public in Action, 6 U Balt J Envir L 1, 7 (1997) ("Government agencies may ... be unwilling to fully enforce applicable laws, responding either to local political pressures or short-term economic opportunities. De. 
lack the resources to discover each instance of underenforcement at the state level and take court action to force the state agencies to regulate.

\section{STATE SOVEREIGN IMMUNITY DOCTRINE AND COOPERATIVE FEDERALISM STATUTES}

The Eleventh Amendment of the Constitution provides that: "The Judicial power of the United States shall not be construed to extend to any suit in law or equity, commenced or prosecuted against one of the United States by Citizens of another State, or by Citizens or Subjects of any Foreign State." While the text of the Eleventh Amendment does not appear to immunize a state from suits brought by its own citizens, the Supreme Court has consistently interpreted the Amendment broadly to mean that "an unconsenting State is immune from suits brought in federal courts by her own citizens as well as by citizens of another state." However, at the time Congress began using the cooperative federalism model, the Court's state sovereign immunity jurisprudence allowed Congress to render states amenable to suit in federal court, either by obtaining constructive waiver of their immunity" or directly abrogating their immunity in laws passed pursuant to its Article I powers."

This understanding changed when the Court handed down Seminole Tribe v Florida ${ }^{12}$ in 1996 and College Savings Bank v Florida Prepaid Postsecondary Education Expense Board ${ }^{.3}$ in 1999. In Seminole

pending on the political leadership in the state, enforcement may even be actively discouraged.").

37 See David M. Whalin, John C. Calhoun Becomes the Tenth Justice: State Sovereignty, Judicial Review, and Environmental Law after June 23, 1999, 27 BC Envir Aff L Rev 193, 239 (2000) (noting that "the federal government does not, and will not, have unlimited prosecutorial resources" to pursue environmental claims against states if private citizens cannot).

38 US Const Amend XI.

39 Edelman v Jordan, 415 US 651, 662-63 (1974). While a literal reading of the Eleventh Amendment might lead to the conclusion that citizens of a state may sue their own state in federal court, this reading was rejected over a century ago in Hans v Louisiana, 134 US 1,15 (1890) (holding that appealing to the letter of the Eleventh Amendment as grounds for "sustaining a suit brought by an individual against a State" is "an attempt to strain the Constitution and the law to a construction never imagined"). That a non-consenting state cannot be sued by citizens of any state remains the modern understanding. See Seminole Tribe v Florida, 517 US 44, 54, 66-68 (1996).

40 See Parden v Terminal Railway of Alabama Docks Department, 377 US 184, 192-93 (1964) (finding that Alabama had consented to suit by operating a railroad in interstate commerce after Congress had conditioned operation upon amenability to suit).

41 See Pennsylvania v Union Gas Co, 491 US 1, 19-20 (1989) (finding that the Commerce Clause granted Congress the power to abrogate state sovereign immunity, on the logic that the Article I grant of power to regulate interstate commerce would be "incomplete without the authority to render States liable in damages").

42517 US 44 (1996).

43527 US 666 (1999). 
Tribe, the Court ruled that Congress did not have the power to abrogate state sovereign immunity except through the exercise of its Fourteenth Amendment enforcement powers." In essence, the Court was saying that since state sovereign immunity is a constitutionally protected right, Congress cannot just legislate it away."

In College Savings, on a narrow reading, the Court ruled that Congress could not obtain constructive waiver of state sovereign immunity merely by specifying that actors-including state actorsparticipating in regulated activity would be subject to suit in federal court. Given some rather stern language in the opinion that casts aspersions on the concept of constructive waiver as an "end-run" around Seminole Tribe's abrogation ban, it is possible to read College Savings more broadly to write constructive waiver out of the law. But the College Savings opinion's acknowledgment of continuing circumstances under which the Court would still find constructive waiver belies any such intention. To the contrary, an examination of these exceptions yields a rule as to what sort of constructive waiver the Court will still allow. Specifically, it will allow a state to constructively waive its immunity by voluntarily accepting a gift or gratuity from the federal government where it is clear from the terms of that gift that, by doing so, it is subjecting itself to suit in federal court. The regulation as waiver theory fits within this rule.

\section{A. Accepted Routes of Private Litigation under Cooperative Federalism Statutes after Seminole Tribe}

Putting the availability of constructive waiver aside, the primary route for private litigation under the cooperative federalism statutes following Seminole Tribe is through Ex Parte Young actions for injunctive relief against state officials for ongoing violations of federal law. State sovereign immunity may also still be abrogated through con-

44 See Seminole Tribe, 517 US at 59 (noting that the Court had previously found congressional authority to abrogate state sovereign immunity only under the Fourteenth Amendment (in Fitzpatrick v Bitzer, 427 US 445 (1976)) and through its Article I powers (in Union Gas)); id at 66 ("Union Gas was wrongly decided and ... should be, and now is, overruled."). The Court maintained that Congress may abrogate state sovereign immunity under the Fourteenth Amendment because $\S 5$ of the Amendment expressly provides that "Congress shall have power to enforce, by appropriate legislation, the provisions of this article," id at 59, and was "adopted well after the adoption of the Eleventh Amendment and the ratification of the Constitution." Id at 66. Thus, the Court stated, "the Fourteenth Amendment ... operated to alter the pre-existing balance between state and federal power achieved by Article III and the Eleventh Amendment." Id at $66-67$.

45 Id at 72-73 ("Even when the Constitution vests in Congress complete law-making authority over a particular area, the Eleventh Amendment prevents congressional authorization of suits by private parties against unconsenting States.... Article 1 cannot be used to circumvent the constitutional limitations placed upon federal jurisdiction."). 
gressional legislation pursuant to the Fourteenth Amendment. ${ }^{46}$ But that exception does not apply to most cooperative federalism statutes, which are passed pursuant to Congress's Article I powers. States may also explicitly waive their immunity, either by voluntarily invoking the jurisdiction of a federal court, ${ }^{4 *}$ or by passing a state statute or state constitutional provision to that effect. ${ }^{49}$ However, in the mine run of cooperative federalism suits, states have declined to waive their immunity, aggressively using state sovereign immunity as a defense.

This means that, in practice, most private citizens seeking to sue state regulators under cooperative federalism statutes now pursue them as Ex Parte Young actions. ${ }^{\text {.0 }}$ Under Ex Parte Young, private citizens may bring equitable suits against state officials to enjoin an ongoing violation of federal law, on the theory that, because a state cannot authorize state officials to violate the law, such officials are no longer acting on the state's behalf." Ex Parte Young plaintiffs may not, however, seek damages or retroactive relief. .2 $^{2}$ Plaintiffs suing under cooperative federalism statutes are generally able to plead correctly under Ex Parte Young, though those that cannot identify a specific state official responsible for the misregulation are knocked out of court. ${ }^{53}$ In at

4h This abrogation would proceed on the logic that the Fourteenth Amendment explicitly authorizes congressional control of the states to ensure equal protection and due process to all United States citizens.

47 See Part II.B.

48 This is known as "waiver-in-litigation." See generally Gil Seinfeld, Waiver in Litigation: Eleventh Amendment Immunity and the Voluntariness Question, 63 Ohio St L J 871 (2002).

49 See College Savings, 527 US at 670, citing Clark v Barnard, 108 US 436, 447-48 (1883).

50) See, for example, Cox $v$ City of Dallas, 256 F3d 281 (5th Cir 2001) (allowing a Resource Conservation and Recovery Act claim to go forward under the theory of Ex Parte Young); Natural Resources Defense Council, Inc v California Department of Transportation, 96 F3d 420 (9th Cir 1996) (Clean Water Act claim); Clean Air Council v Mallory, 226 F Supp 2d 705 (ED Pa 2002) (Clean Air Act claim); Swartz v Beach, 229 F Supp 2d 1239 (D Wyo 2002) (various Clean Water Act claims); West Virginia Highlands Conservancy v Norton, 137 F Supp 2d 687, 691-92 (SD W Va 2001) (allowing a Surface Mining Control and Reclamation Act suit to go forward under the theory of Ex Parte Young, after noting that the Supreme Court had disfavored constructive waivers in College Savings); Froebel v Meyer, 13 F Supp 2d 843 (ED Wis 1998) (Clean Water Act claim).

51 See generally Ex Parte Young, 209 US 123. This arises out of the famous fiction that a state officer's action that violates federal or constitutional law is ultra vires and therefore "stripped of its official or representative character." Id at 160.

52 See Edelman v Jordan, 415 US at 667-69 (rejecting an injunction granted in an Ex Parte Young action ordering payment of previously owed benefits); Quern v Jordan, 440 US 332, 337 (1979) ("The distinction between that relief permissible under the doctrine of Ex Parte Young and that found barred in Edelman was the difference between prospective relief . . . and retrospective relief.").

53 See, for example, Peat $v$ EPA, 175 F3d 422, 429 (6th Cir 1999) (ruling that plaintiff could not sue the director of the Michigan Department of Environmental Quality for a Clean Water Act claim, because it "failed to allege that the Director has individually taken actions which constitute continuing violations of federal law") (emphasis added); Sweat v Hull, 200 F Supp 2d 1162, 1175 (D Ariz 2001) (dismissing plaintiff's Clean Air Act claim against the Governor of Arizona for failure to show defendant's link to the claim). 
least one recent case, the plaintiffs' Ex Parte Young claim was dismissed despite the fact that they named state officials and sought prospective equitable relief because their brief "contained no sustained argument in support of their claim.",4

The obstacles to Ex Parte Young suits do not end here. In Pennhurst State School \& Hospital v Halderman, ${ }^{\text {ss }}$ the Court made clear that plaintiffs may only bring Ex Parte Young actions for violations of federal-not state-law. ${ }^{\text {s6 }}$ States, citing Pennhurst, have asserted that their officers are immune for misregulation of state portions of cooperative federalism statutes. The logic of this defense is that, because the state implementation plans are devised by the states, albeit according to federal standards, they are state, rather than federal, law. At least one circuit court has accepted this argument with respect to one of the original cooperative federalism statutes, the Surface Mining Control and Reclamation Act."

Two recent Supreme Court cases have rendered the availability of Ex Parte Young suits somewhat uncertain-something that state defendants are also taking aggressive advantage of. ${ }^{\text {s. }}$ In Seminole Tribe, the Supreme Court also ruled on Ex Parte Young, cautioning that it was a narrow exception to Eleventh Amendment immunity, and that Ex Parte Young suits should not be allowed to go forward where Congress had laid out a "detailed remedial scheme" for enforcement through other means. ${ }^{59}$ Thus, as each federal court entertains an $E x$ Parte Young suit under a given statute for the first time, it must conduct an inquiry into whether Congress laid out a detailed, as opposed to limited, remedial scheme in that statute - the former indicating, under the reasoning of Seminole Tribe, that Congress intended to foreclose the possibility of prospective injunctive relief. ${ }^{80}$

54 Rhode Island Department of Environmental Management v United States, 304 F3d 31, 52 (1st Cir 2002).

55465 US 89 (1984).

56 Id at 106 (concluding that Ex Parte Young is "inapplicable in a suit against state officers on the basis of state law").

57 See Bragg $v$ West Virginia Coal Association, 248 F3d 275, 297-98 (4th Cir 2001) (concluding that a congressional invitation to a state to create its own laws under a federal program makes the state laws exclusive and state officers immune from suit under Ex Parte Young).

58 See, for example, Rosie D. v Swift, 310 F3d 230, 231-32 (1st Cir 2002):

In recent years, the Supreme Court has redefined the calculus of federalism, tilting the scales more and more toward states' rights. This appeal represents an attempt by the named defendants-a complement of Massachusetts officials, including the governor, two cabinet officers, and the Commissioner of the Division of Medical Assistance - to capitalize upon that trend. As we explain below, they seek to push the envelope too far.

s9 Seminole Tribe, 517 US at 74-76.

60 See, for example, Mountain Cable Co v Public Service Board of Vermont, 242 F Supp 2d 400 (D Vt 2003) (in attempting to determine whether the Seminole Tribe exception to Ex Parte Young applies to the Cable Communications Policy Act, asking: "Does the remedial scheme in the Cable Act more closely resemble the Indian Gaming Regulatory Act ('IGRA') at issue in 
Ex Parte Young was further whittled away in Idaho $v$ Coeur d'Alene Tribe of Idaho," in which Justice Kennedy suggested in the principal opinion that Ex Parte Young is not applicable to every suit for prospective relief against an individual officer for an ongoing violation of federal law, advocating a case-by-case balancing inquiry into federal and state interests. ${ }^{62}$ Because this section of the opinion was joined only by Chief Justice Rehnquist, some circuits have rejected the case-by-case inquiry. ${ }^{6.3}$ However, all agree that Coeur d'Alene creates an exception to Ex Parte Young where "the suit against the state officer affects a unique or essential attribute of state sovereignty."

In sum, though the Ex Parte Young doctrine is still available to plaintiffs seeking to sue the states for misregulation under cooperative federalism statutes, in practice its utility is diminished by the number of exceptions and limitations to the doctrine. States do raise, and courts must consider, each and every exception as a defense, raising the cost and burden of litigation to plaintiffs.

\section{B. Status of the Waiver Exception to State Sovereign Immunity}

In College Savings, the Supreme Court noted that it had "long recognized that a State's sovereign immunity is 'a personal privilege which it may waive at its pleasure."'"s5 Thus, it did not dispute the proposition that a state may explicitly waive its immunity to suit in federal court. But it overruled the main case, Parden $v$ Terminal Railway of Alabama Docks Department, ${ }^{\text {th }}$ that allowed a state to constructively waive its immunity in federal court-and in language casting great doubt on the continuing validity of the concept. ${ }^{6 .}$ And yet, the Court did acknowledge that in at least two situations it had allowed Congress to exchange a "gift or gratuity" for a waiver of immunity or other "action[] that Congress could not require them to take." The

Seminole Tribe (in which case, Ex parte Young does not apply), or the 1996 Act (in which case Ex parte Young does apply)?").

61521 US 261 (1997).

62 Id at 270.

63 See, for example, MCI Telecommunications v Bell-Atlantic Pennsylvania Services, 271 F3d 491, 508 (3d Cir 2001).

64 Id.

65 College Savings, 527 US at 675, quoting Clark, 108 US at 447. See also Seminole Tribe, 517 US at 65 (calling the proposition that the States may waive their sovereign immunity "unremarkable").

$66 \quad 377$ US 184 (1964).

67 See, for example, College Savings, 527 US at 678 (noting, in a review of post-Parden case law, that " $\mathrm{t}]$ he next year, we observed (in dictum) that there is "no place' for the doctrine of constructive waiver in our sovereign-immunity jurisprudence"). See also id at 680 ("We think that the constructive-waiver experiment of Parden was ill conceived, and we see no merit in attempting to salvage any remnant of it.").

68 Id at $686-87$. 
evident tension between the Court's tone in overruling Parden and its reservation of the possibility of constructive waiver in certain circumstances has resulted in conflicting interpretations in the lower courts.

For the thirty-five years prior to College Savings, the Court allowed Congress to obtain a constructive waiver of state sovereign immunity where a state took part in a regulated activity. The leading case on this was Parden, where the Court found that, because Congress had clearly conditioned the exercise of the right to operate an interstate railroad upon amenability to suit in federal court, when a state exercised that right, it was "taken to have accepted that condition and thus to have consented to suit." ${ }^{\prime 69}$ This stood for the proposition that constructive waiver occurred where (i) Congress clearly notified a state that it would render itself amenable to suit by engaging in a certain activity, and (ii) the state engaged in such activity.

College Savings, in which Florida was defending itself against a suit for false and misleading advertising under the Trademark Remedy Clarification Act, expressly overruled Parden as out of synch with the rest of the Court's sovereign immunity doctrine. ${ }^{70}$ First, the Court said, it could not square Parden with its line of cases requiring that "a State's express waiver of sovereign immunity be unequivocal." The Court wanted to be certain that a state in fact consented to suit, but found little reason to assume actual consent based upon "the State's mere presence in a field subject to congressional regulation." ${ }^{\prime 2}$ Presence in a regulated industry that a state is perfectly entitled to enter does not indicate any voluntary consent to suit, as the alternative would be the congressionally imposed sanction of being excluded from otherwise lawful activity. I take this to put the following stricture, at least, on constructive waiver: It must be certain that a state consents to suit; merely engaging in an otherwise permissible activity is insufficient to show this, because it lacks any indication of voluntariness.

Similarly, the Court reasoned that for Congress to "exact constructive waivers of sovereign immunity through the exercise of Article I powers would ...., as a practical matter, permit Congress to circumvent the antiabrogation holding of Seminole Tribe." "In Seminole Tribe, the Court meant to foreclose Congress from forcing a state to give up its constitutional rights ${ }^{74}$ by straightforwardly abrogating the

69 377 US at 192.

70 See 527 US at 680 ("Whatever may remain of our decision in Parden is expressly overruled.").

71 Id, citing Great Northern Life Insurance Co v Read, 322 US 47 (1944).

72 College Savings, 527 US at 680.

73 Id at 683 ("Forced waiver and abrogation are not even different sides of the same coin they are the same side of the same coin.").

74 Something that is intuitively impermissible, as Congress cannot force any person or state to give up their constitutional rights. 
right in a statute; the Court would not allow Congress to do the equivalent in a Parden-type situation by inferring waiver from actions that are not truly voluntary.

Additionally, the Court said, it was "anomalous to speak of the 'constructive waiver' of a constitutionally protected privilege."' The Court explained:

For example, imagine if Congress amended the securities laws to provide with unmistakable clarity that anyone committing fraud in connection with the buying or selling of securities in interstate commerce would not be entitled to a jury in any federal criminal prosecution of such fraud. Would persons engaging in securities fraud after the adoption of such an amendment be deemed to have "constructively waived" their constitutionally protected rights to trial by jury in criminal cases? . . . The answer is of course, no. ${ }^{76}$

It seems as if the Court's meaning here is that a state can never constructively "surrender its constitutional right []" to sovereign immunity-just as a con man cannot be deemed, minus explicit waiver through a plea bargain or otherwise, to have surrendered his right to a jury trial.

Yet, the Court went on to acknowledge that Congress could obtain constructive waiver in at least one instance. The Court noted that under Petty $v$ Tennessee-Missouri Bridge Commission, ${ }^{7 *}$ the Court allows Congress to obtain constructive waiver in return for congressional approval of interstate compacts. ${ }^{70}$ The Court also acknowledged that in cases such as South Dakota $v$ Dole, it allows Congress to "condition its grant of funds to the States upon their taking certain actions that Congress could not require them to take, and that acceptance of the funds entails an agreement to the actions." "Wh While the "certain action" at issue in Dole was not a waiver, ${ }^{\text {k2 }}$ the Court's point was that Congress may ask the states to do something that it could not require them to do in exchange for the "gift" of federal funds. ${ }^{\mathrm{k}}$ This, by

75 Id at 682.

76 Id at 681-82.

77 Id at 681 , quoting Edelman, 415 US at 673.

$78 \quad 359$ US 275 (1959).

79 See College Savings, 527 US at 686 ("In [Petty], we held that a bistate commission which had been created pursuant to an interstate compact (and which we assumed partook of state sovereign immunity) had consented to suit by reason of a suability provision attached to the congressional approval of the compact.").

80 483 US 203 (1987).

81 College Savings, 527 US at 686, citing Dole, 483 US 203.

${ }^{8}$ Instead, it was agreeing to raise the state drinking age to twenty-one. See Dole, 483 US at 205

83 See College Savings, 527 US at 686-87 ("Congress has no obligation to use its Spending 
implication, was the principle at work in Petty, where Congress was allowed to ask the states to waive their sovereign immunity in exchange for the "gratuity" of permission to form an interstate compact."

Connecting the dots between what the Court forbids and what it acknowledged it still allows in College Savings, it follows that a constructive waiver of state sovereign immunity may still be found where (i) Congress offers a "gift" or "gratuity" as seen in Dole or Petty in exchange for a state waiver of state sovereign immunity, (ii) the terms of the legislation make it clear that by accepting the gift or gratuity, the state in fact consents to suit, and (iii) acceptance of that gift or gratuity is truly voluntary. Voluntariness is the touchstone: Where the "inducement offered by Congress [is] so coercive as to pass the point at which "pressure turns into compulsion,"," the offer of that inducement would be an unconstitutional condition, destroying the voluntariness of the waiver.

\section{Regulation as Waiver}

Since College Savings, the Supreme Court has not approved any further instances of constructive waiver. Some circuit courts have begun to apply College Savings to find a voluntary waiver of state sovereign immunity in exchange for grants of federal funds. ${ }^{\mathrm{k} 7}$ However, several circuits have advanced a theory of regulation as waiver to uphold the private litigation provision of the 1996 Telecom Act, which, they believe, fits within the strictures of College Savings.

In two cases interpreting the citizen suit provision of the 1996 Telecom Act, the Seventh and Tenth Circuits argued that when a state takes up the opportunity to act as a regulator in a field from which it would otherwise be preempted by federal legislation, it is accepting a "gift or gratuity" for which Congress may obtain a constructive waiver of immunity after College Savings.

Clause power to disburse funds to the States; such funds are gifts.").

84 See Petty, 359 US at 277 (discussing the terms of the compact); College Savings, 527 US at 686 ("[Petty] seem[s] to us fundamentally different from the present [case]. Under the Compact Clause,... States cannot form an interstate compact without first obtaining the express consent of Congress; the granting of such consent is a gratuity.").

85 College Savings, 527 US at 687 (internal citations omitted).

86 Id.

87 See, for example, Koslow v Pennsylvania, 302 F3d 161 (3d Cir 2002), cert denied, 537 US 1232 (2003) ("[T]he Commonwealth could avoid $\$ 504$ claims against the Department of Corrections by declining all federal funds to the Department of Corrections. . . By accepting SCAAP funds, the Commonwealth opens the Department of Corrections to suits under the Rehabilitation Act.").

8x See MCI Telecommunications Corp v Illinois Bell Telephone Co, 222 F3d 323, 343 (7th Cir 2000), cert denied, 531 US 1132 (2001) (holding that Congress may obtain a constructive waiver by granting a state the "gratuity" of participating in regulatory activity that would otherwise be foreclosed by federal occupation of the field); MCI Telecommunications Corp v Public 
The argument in essence has two parts. First, because the Telecom Act includes provisions both offering the states the opportunity to participate in regulation of the local telecommunications market, and subjecting state regulators to suit for their regulation when the states accept the opportunity to regulate, when states enact regulations, they are indicating their willingness to be subject to suit. Second, Congress offered the states a valid "gratuity" in exchange for that waiver: Once Congress had decided to pass comprehensive telecommunications legislation, states could no longer regulate the industry unless Congress carved out a specific role for them. ${ }^{k 9}$ The offer to the states of the opportunity to regulate is, therefore, a "gratuity," and states' acceptance of that offer voluntary.

The Third and Fifth Circuit have embraced the Seventh and Tenth Circuits' regulation as waiver theory." The Fourth and Sixth Circuits, however, have rejected the theory."

The Sixth Circuit rejected the theory rather peremptorily. ${ }^{2}$ In Bell Atlantic Maryland v MCI Worldcom, ${ }^{, 3}$ the Fourth Circuit argued that nothing about the state's decision to take up the opportunity to regu-

Service Commission of Utah, 216 F3d 929, 938 (10th Cir 2000), cert denied, 531 US 1183 (2001) (holding that, because "Congress could have preempted all state regulation of local phone service," the opportunity to regulate under the Act was a "federal gratuity" in exchange for which the states could constructively waive their immunity).

sy See $M C l \cup$ Utah, 216 F3d at 938 ("[W]ith the passage of the 1996 Act, Congress essentially transformed the regulation of local phone service from an otherwise permissible state activity into a federal gratuity."); MCI v Illinois Bell, 222 F3d at 343 (holding that, because "Congress[] exercising its authority to regulate commerce has precluded all other regulation except on its terms," the authority of states to regulate is not derived "from their own sovereign authority").

9) See MCI Telecommunications Corp v Bell Atlantic-Pennsylvania Services, Inc, 271 F3d 491, 505 (3d Cir 2001) (having laid out the regulation as waiver theory, noting that the Fifth, Seventh, and Tenth Circuits had also accepted it); AT\&T Communications v BellSouth Telecommunications, 238 F3d 636, 645 (5th Cir 2001):

[W]e agree with the Tenth and Seventh Circuits' conclusion that, after College Savings, Congre: may still obtain a non-verbal voluntary waiver of a state's Eleventh Amendment immunity, if the waiver can be inferred from the state's conduct in accepting a gratuity after being given clear and unambiguous statutory notice that it was conditioned on waiver of immunity,

The Fifth Circuit concluded that because "Congress pre-empted the states in the regulation of local telecommunications competition with regard to all matters addressed by the Act," the state defendant "waived its state immunity when it accepted the Congressional offer of a gratuity." Id at 639.647.

91 See Bell Atlantic Maryland v MCI Worldcom,240 F3d 279 (4th Cir 2001); Michigan Bell v Climax Telephone, 202 F3d 862 (6th Cir 2000).

y2 See Climax Telephone, $202 \mathrm{~F} 3 \mathrm{~d}$ at $867 \mathrm{n} 2$ (while agreeing with the result in the original Seventh Circuit case, heard prior to College Savings, that the suit should go forward, noting that it did "not base [its] decision on the reasoning in that case because the [Seventh Circuit] reached its decision by applying the constructive waiver doctrine, which has since been limited by the Supreme Court").

93240 F3d 279 (4th Cir 2001). 
late as offered by the Act indicated an "unequivocal indication that [the] State intends to consent to federal jurisdiction" that it thought the Supreme Court required. ${ }^{94}$ It went on to cite College Savings as support for this proposition-echoing that "there is little reason to assume actual consent based upon the State's mere presence in a field subject to congressional regulation."."5 But this misses the mark. There may be little reason to assume actual, unequivocal consent to suit based upon state participation in a regulated activity such as running an interstate railroad (as in Parden) or more general commercial activities (as in College Savings). It does not necessarily follow, however, that a state's acceptance of an invitation to participate as a regulator in a field from which it would otherwise be excluded by preemptive federal regulation does not rise to the level of unequivocal, voluntary consent required by College Savings. But the Fourth Circuit did not move beyond the College Savings citation to address that line of reasoning.

The Supreme Court appeared ready to resolve the circuit split on whether regulation as waiver is a valid theory of constructive waiver in the Telecom Act in 2002, but ultimately allowed the suit to go forward as an Ex Parte Young action. Thus, it is open to question whether Congress may obtain constructive waiver of a state's sovereign immunity by offering it the opportunity to regulate in an area subject to federal regulation.

\section{PARTICIPATION IN REgUlation AS Waiver of STATE SOVEREIGN IMMUNITY IN THE COOPERATIVE FEDERALISM CONTEXT: AN APPROPRIATE ABROGATION}

As presented in Part II, regulation as waiver occurs when a state takes up the opportunity to act as a regulator in a field from which it would otherwise be preempted pursuant to federal legislation that also clearly subjects state regulators to suit. Regulation as waiver via the Telecom Act fits within the contours of the constructive waiver doctrine laid out in College Savings. This naturally extends to all cooperative federalism statutes that contain provisions authorizing private litigation against state regulators.

\section{A. Regulation as Waiver and Current Constructive Waiver Doctrine \\ After College Savings, a constructive waiver of state sovereign immunity may still be found where (i) Congress offers a "gift" or "gra- tuity" in exchange for a state waiver of state sovereign immunity,}

\footnotetext{
94 Id at 293, citing Atascadero State Hospital v Scanlon, 473 US 234, 238 n 1 (1985).

95 Bell Atlantic Maryland, 240 F3d at 293, citing College Savings, 527 US at 680.

96 See note 13.
} 
(ii) the terms of the legislation make it clear that by accepting the gift or gratuity, the state in fact consents to suit, and (iii) acceptance of that gift or gratuity is truly voluntary. As I will explain here, regulation as waiver in the context of the Telecom Act meets these requirements.

First, in the context of the Telecom Act, we must determine whether the opportunity to participate in a cooperative regulatory scheme can fairly be characterized as a "gratuity." In College Savings itself, the Court drew the line between a "gift or gratuity," for which Congress may obtain constructive waiver, and a "sanction,", for which it may not. A sanction, typified by Parden, is the threat of exclusion from an otherwise lawful activity. A gift, exemplified by Dole, is the grant of money through the Spending Clause, which "Congress has no obligation to use" and which the state has the option to decline. A gratuity, exemplified by Petty, is a grant of consent to do something that states do not otherwise have permission to do." The "something" in Petty was the opportunity to participate in a bi-state commission, something that, under the Compacts Clause, the Constitution dictates that states may do only with Congress's permission."'

The opportunity to regulate offered under the Telecom Act looks much more like a gratuity than a sanction. Congress is not denying the states the opportunity to engage in otherwise lawful activity - that opportunity disappeared under preemption doctrine as soon as Congress occupied the field. Instead, it is offering them permission to participate in the regulation of local telecommunications, an offer that it has no obligation to make. Congress's grant of permission to the states to continue to regulate local telecommunications is therefore a gratuity within the meaning established in College Savings.

Second, to determine what constitutes a clear enough indication that, by accepting a gratuity, the state consents to suit, it is useful to again look to Petty. In Petty, a bi-state commission formed to build a bridge was deemed to have waived its state sovereign immunity ${ }^{\text {III }}$ through commencing to operate under the congressional document authorizing the compact through which it was formed. As explained by the Court in Petty:

The compact prepared by the two States and submitted to the Congress provided in Art. I, $\S \S 1$ and 2, that respondent should have the power to build a bridge and operate ferries across the

97 College Savings, 527 US at 687.

98 Id at 686-87.

99 See id ("States cannot form an interstate compact without first obtaining the express consent of Congress; the granting of such consent is a gratuity.").

100 US Const Art I, $\S 10, \mathrm{cl} 3$ ("No State shall, without the consent of Congress, ... enter into any agreement or compact with another State.").

101 The Court assumed the commission partook of state sovereign immunity. 
Mississippi at specified points and in Art. I, § 3, that it should have the power "to contract, to sue and be sued in its own name."112

In College Savings, the Court explained that in Petty, constructive waiver adhered "by reason of [the] suability provision attached to the congressional approval of the compact." "11.5 In other words, that the compact simultaneously provided for the creation and suability of the commission was sufficient to create constructive waiver, even absent an explicit provision stating that, by commencing activity, the commission waived its immunity.

The 1996 Telecom Act has very similar provisions. Section 251 of the Act provides state commissions with primary responsibility for enforcing interconnection agreements. ${ }^{104}$ Section 252 of the Act provides that "[i]n any case in which a State commission makes a determination under this section, any party aggrieved by such determination may bring an action in an appropriate Federal district court to determine whether the agreement or statement meets the requirements [of the Act]."

Finally, we must look to see whether states' acceptance of the opportunity to regulate is truly voluntary, or whether the cost of turning down that opportunity is so great that the acceptance can only be deemed to be coerced. In College Savings, the Court cautioned that conditions attached to federal gratuities "might be so coercive as to pass the point at which "pressure turns into compulsion." "This, the Court said, would be an unconstitutional condition, destroying the voluntariness of the waiver. ${ }^{107}$ To get at whether an opportunity to act as a regulator in a preempted field is coercive, or something which states can be deemed to have accepted voluntarily, it is useful to look at the Court's prior opinions on federal coercion of the states.

In College Savings, the Court tells us that "the point of coercion is passed, and the voluntariness of waiver destroyed ... when what is attached to the refusal to waive is the exclusion of the State from otherwise lawful activity."' Thus, we know from College Savings itself, and its treatment of Parden, that the threat of exclusion from otherwise lawful, regulated activity, such as advertising services or running an interstate railroad, is coercive. This is not all that helpful, though,

112 Petty, 359 US at 277.

103 College Savings, 527 US at 686.

104 See 47 USC $\$ 251$ (d) (“[T] he Commission shall complete all actions necessary to establish regulations to implement the requirements of this section.")

105 Id $\S 252(\mathrm{e})(6)$.

106 College Savings, 527 US at 687 (internal citations omitted).

107 Id.

108 Id. 
since the fact that the opportunity to participate in a regulated industry is not a gratuity itself defeats those exchanges.

Turning to the cases the Court has upheld as involving voluntary exchanges, we know from Petty that the opportunity to participate in a bi-state commission at Congress's invitation is not a coercive inducement when offered in exchange for a waiver of state sovereign immunity. Further, we know from Dole, in which the Court upheld a statute granting the last 5 percent of federal highway funds to the states in exchange for an agreement to raise the drinking age to twenty-one, that such an inducement is not coercive. ${ }^{1 \text { ity }}$ Applying this to the state sovereign immunity context, the Third Circuit held in 2002 that offering federal prison funds in exchange for a waiver of immunity was not coercive, because; " $[\mathrm{t}]$ hough this 'sacrifice' would doubtless result in some fiscal hardship - and possibly political consequences - it is a free and deliberate choice by the Commonwealth that does not rise to the level of an "unconstitutional condition.","10

In addition, the Court has explicitly differentiated the offer of an opportunity to regulate through cooperative federalism schemes from impermissible congressional coercion."' In Hodel v Virginia Surface Mining and Reclamation Association, Inc, ${ }^{1,2}$ the Court upheld the Surface Mining Control and Reclamation Act, under which the states regulate mining according to national standards, because:

[T] he States are not compelled to enforce the [federal] standards, to expend any state funds, or to participate in the federal regulatory program in any manner whatsoever. If a State does not wish to submit a proposed permanent program that complies with the Act and implementing regulations, the full regulatory burden will be borne by the Federal Government."

Similarly, in FERC v Mississippi, ${ }^{114}$ the Court upheld the Public Utility Regulatory Policies Act, which encouraged the states to develop programs dealing with the national energy crisis according to federal proposals, in part because, "if a State has no utilities commission, or sim-

109 See Dole, 483 US at 211 ("[Because] all South Dakota would lose if she adheres to her chosen course as to a suitable minimum drinking age is $5 \%$ of the funds otherwise obtainable under specified highway grant programs, the argument as to coercion is shown to be more rhetoric than fact.").

110 Koslow v Pennsylvania, 302 F3d 161 (3d Cir 2002), cert denied, 537 US 1232 (2003).

111 See New York v United States, 505 US 144, 167 (1992) ("[W]here Congress has the authority to regulate private activity under the Commerce Clause, we have recognized Congress' power to offer States the choice of regulating that activity according to federal standards or having state law pre-empted by federal regulation.").

112452 US 264 (1981).

113 Id at 288.

114456 US 742 (1982). 
ply stops regulating in the field, it need not even entertain the federal proposals." "1s

It follows that accepting the exchange offered in the Telecom Act is not past "the point of coercion" demarcated in College Savings. Under the Telecom Act, states can either regulate, or step out of the way and allow the federal government to regulate: Like other cooperative federalism statutes, the Telecom Act "allows a state to choose whether it will participate in the federal regulatory scheme." commission chooses not to act, the Federal Communications Commission will assume the state commission's responsibility for supervising the interconnection agreements." While the choice to regulate may have certain definable benefits to the states-making sure that the regulation of the industry is tailored to local needs, for instance-that choice can hardly be called irresistible.

B. Potential Application of Regulation as Waiver to the Cooperative Federalism Model as a Whole

The regulation as waiver theory offered by the Seventh and Tenth Circuits potentially applies to all cooperative federalism statutes in which Congress has seen fit to include private litigation clauses. First, by definition, the opportunity to act as a regulator alongside the federal government is offered to the states in all cooperative federalism statutes as an alternative to being preempted. The Court itself defines cooperative federalism statutes as federal laws that "offer States the choice of regulating [certain] activity according to federal standards or having state law pre-empted by federal regulation." ${ }^{\prime \prime 18}$ This means that the gratuity and unmistakability requirements are satisfied.

Echoing the argument made above in the context of the Telecom Act, the opportunity for states to regulate in fields that fall within the ambit of the federal government's enumerated powers is a gratuity once the federal government has decided to regulate in that area. The federal government is under no obligation to include states in regulation of those areas: States "exercise regulatory authority only by congressional grace."1"19

Further, the mechanism by which this waiver is obtained is generally clear. Just as the proximate authorization and sue-or-be-sued clauses in the interstate compact in question in Petty were a suffi-

115 Id at 764.

116 MCI Telecommunications Corp v Public Service Commission of Utah. 216 F3d 929, 934 (10th Cir 2000).

117 See 47 USC $\$ 252(\mathrm{e})(6)$.

I18 New York, 505 US at 167, citing Hodel, 452 US at 288.

119 John P. Dwyer. The Role of State Law in an Era of Federal Preemption: Lessons from Environmental Regulation, 60 L \& Contemp Probs 203, 203 (1997). 
ciently clear indicator of consent, so should side-by-side clauses in cooperative federalism statutes offering states the choice of regulating, on the one hand, and authorizing private litigation, on the other.

Finally, state participation as regulators in cooperative federalism regulatory schemes is always voluntary. Again echoing what was said above, cooperative federalism statutes give states the choice of either regulating, or stepping out of the way and allowing the federal government to regulate. For example, under the Clean Air Act, the states are instructed to create and implement "state implementation plans" for regulating pollutants; should they choose not to, the EPA will devise a "federal implementation plan" to achieve national air quality standards in that state.

In fact, as noted above, the Supreme Court has long recognized the voluntary nature of cooperative federalism schemes. Twice prior to the current "federalism revolution," the Court upheld cooperative regulatory schemes against commandeering challenges - in Hodel, and in FERC v Mississippi. ${ }^{121}$ More recently, in New York v United States, after announcing that "Congress may not simply "commandee[r] the legislative processes of the States by directly compelling them to enact and enforce a federal regulatory program,",'23 the Court identified cooperative federalism as among "a variety of methods ... by which Congress may urge a State to adopt a legislative program consistent with federal interests." ${ }^{124}$ Cooperative federalism statutes, the Court explained, are voluntary because they reserve to "the residents of the State ... the ultimate decision as to whether or not the State will comply."

Indeed, the Court acknowledged that it is completely conceivable that "[i]f state residents would prefer their government to devote its attention and resources to problems other than those deemed important by Congress, they may choose to have the Federal Government rather than the State bear the expense of a federally mandated regula-

120 See Clean Air Council v Mallory. 226 F Supp 2d 705, 708-09 (ED Pa 2002).

121 See Hodel. 452 US at 288 (after noting that the Surface Mining Reclamation Act gives states the choice of either implementing a regulatory program in accordance with federal standards or stepping aside and letting the federal government regulate, holding that "there can be no suggestion that the Act commandeers the legislative processes of the States by directly compelling them to enact and enforce a federal regulatory program"); FERC v Mississippi, 456 US at 765 (upholding the Public Utility Regulatory Policy Act's requirement that state utility regulators consider adopting ratemaking standards proposed by the FERC).

122505 US 144 (1992).

123 Id at 161, quoting Hodel, 452 US at 288.

$124505 \mathrm{US}$ at $166-67$.

125 Id at 168 . It is also worth noting that. should states not believe that, in a particular area. the cooperative federalism model is appropriate or worthwhile, they can prevent the passage of such a statute through the political process. as they can be "powerful political actors" in Congress. See Dwyer. $60 \mathrm{~L} \&$ Contemp Probs at 203 (cited in note 119). 
tory program. ${ }^{, 26}$ Similarly, if states prefer to maintain their sovereign immunity rather than to regulate in a certain area that has been preempted by Congress, they may choose to have the federal government bear the risk of being subject to suit for misregulation.

\section{Regulation as Waiver and the Policy Goals behind the Court's Federalism Doctrine}

The regulation as waiver theory not only fits within the letter of constructive waiver doctrine as established by College Savings; it also serves the broader policy concerns of the "federalism revolution." By revitalizing the rights-vindication and citizen suit provisions of cooperative federalism statutes, it may help preserve that legislative structure - and with it, a strong role for the states in federal regulation-as an attractive option for members of Congress concerned with passing enforceable statutes.

Congress's goals in adopting the cooperative federalism model are remarkably similar to the Supreme Court's goals in advancing the current federalism revival. Once Congress has decided that federal legislation is needed, several main policy-design factors motivate Congress to adopt the cooperative federalism model in place of a unitary federal model. First, the cooperative federalism model allows Congress to "tailor federal regulatory programs to local conditions." "27 Local regulators have unique knowledge of local conditions and therefore of the regulatory tools most effective for combating specific problems, ${ }^{128}$ which in turn allows them to avoid potentially welfarereducing, one-size-fits-all approaches. ${ }^{12 y}$ Second, cooperative federalism "promote[s] competition within a federal regulatory framework." "1wit Third, it "permit[s] experimentation with different ap-

126 New York, 505 US at 168.

127 Weiser. 76 NYU L Rev at 1698 (cited in note 17). See also Dwyer. 60 L \& Contemp Probs at 203 (cited in note 119) ("The need to tailor environmental policy to local conditions ... compel[s] Congress to share some of its authority.").

128 See Joshua D. Sarnoff. Cooperative Federalism, the Delegation of Federal Power, and the Constitution. 39 Ariz L Rev 205.213 (1997) ("State officials may be better situated than federal bureaucrats to assess local conditions and citizen preferences.").

129 See Dwyer. 60 L \& Contemp Probs at 220 (cited in note 119) (noting that, in the area of environmental regulation. major variations in climate. weather, environmental risks, types of pollution, economic conditions, and preferences for environmental protection make it "highly unlikely that a single, national approach to implementation and enforcement would succeed"). See also Michelle Cole, Environmental Oversight Is Slipping Away, Oregonian Al (Feb 26, 2003) (noting that the possibility that the EPA may have to step in and take over local environmental permitting programs in the face of an Oregon budget crisis "is something neither industry nor conservationists want" because, according to a member of the Oregon Department of Environmental Quality (DEQ) advisory committee, "when direction comes out of Washington D.C., and then Seattle and then down to Oregon, you tend to get a one-size-fits-all solution to everything [whereas] DEQ is closer to the issues and able to tailor things better").

130) Weiser, 76 NYU L Rev at 1698 (cited in note 17). 
proaches that may assist in determining an optimal regulatory strategy." "Finally, this model allows Congress to leverage existing state bureaucracies, rather than expend resources on duplicate bureaucracies. ${ }^{132}$

The first three reasons that Congress is typically motivated to adopt cooperative federalism statutes match the reasons presented by the Court in Gregory v Ashcroft ${ }^{133}$ for its efforts to protect "our federalism." According to the Court, our federalism (i) "assures a decentralized government that will be more sensitive to the diverse needs of a heterogeneous society"; (ii) "makes government more responsive by putting the States in competition for a mobile citizenry"; ;" and (iii) "allows for more innovation and experimentation in government." ${ }^{\text {,:s }}$ Further, that cooperative federalism allows Congress to leverage existing state bureaucracies should also please federalism advocates, insofar as the alternative is to set up a federal presence in every state.'

As discussed in Part I, when Congress invites the states to participate as a regulator alongside the federal executive branch through cooperative federalism statutes, it generally includes provisions that subject the states to suit. This constraint-one that Congress has thought necessary to impose upon federal agencies as well-is meant to protect the rights of the regulated community as well as ensure proper implementation of those statutes. But without either Ex Parte Young or some sort of constructive waiver theory, ensuring proper implementation becomes more difficult.

As discussed in Part II.A, since Seminole Tribe, private parties wishing to bring claims against the states for misregulation under cooperative federalism statutes have been required to pursue them as equitable Ex Parte Young suits to constrain future actions of state regulators. In practice, however, the many exceptions and limitations to Ex Parte Young mean that litigating through this route is at best dif-

131 Id

132 See Sarnoff, 39 Ariz L Rev at 213 (cited in note 128) ("Congress may believe that state regulation or implementation will result in resource savings and economies of scale. State bureaucracies may already exist, allowing Congress to rely upon existing resources and regulatory expertise."); Dwyer, $60 \mathrm{~L}$ \& Contemp Probs at 203 (cited in note 119) (discussing Congress's "important need to use state technical and personnel resources" to carry out its regulatory schemes).

133501 US 452 (1991).

134 Id at 458, citing Michael W. McConnell, Federalism: Evaluating the Founders' Design, 54

U Chi L Rev 1484, 1491-1511 (1987).

135501 US at 458.

136 Id.

137 See Weiser, 76 NYU L Rev at 1695 (cited in note 17) (noting that in all areas subject to its Article I powers, Congress could simply "preempt[] the authority of state agencies and supplant[] them with federal branch offices"). 
ficult and at worst uncertain. A theory of constructive waiver, therefore, could considerably strengthen private citizens' opportunities to vindicate rights affected by cooperative federalism statutes and provide needed assistance in ensuring their enforcement, as Congress imagined in including a private litigation provision in those statutes.

To judge the importance of this, imagine if neither Ex Parte Young nor constructive waiver were available to private plaintiffs seeking redress under cooperative federalism statutes. The safeguards on the rights of the regulated community and the enforcement guarantees that Congress intended to provide would be considerably diminished. One might counter that the federal government retains the option of suing the states directly to assure that they properly enforce their portions of cooperative federalism statutes. But the executive branch does not have the resources to police state compliance with federal law. As Justice Souter noted in his dissent to Alden v Maine, "unless Congress plans a significant expansion of the National Government's litigating forces to provide a lawyer whenever private litigation is barred by today's decision and Seminole Tribe, the allusion to enforcement of private rights by the National Government [made by the majority] is probably not much more than whimsy.",1.99

It is also conceivable that state regulators would be deterred from misregulation or failure to regulate by the knowledge that, should they fall down on the job, Congress could simply replace the cooperative federalism structure with unitary federal regulation, and thereby extinguish their role in regulation. But this does not provide adequate deterrence, for two reasons. First, it is hard to conceive that individual regulatory agencies would really feel that, should they misstep in carrying out the regulation as applied to their particular state, Congress would replace the entire statute. Second, and more saliently, the legislative inertia that must be overcome at the national level to pass a new statute makes this an insufficient check.

What happens, then, in this alternate universe? We can stipulate that where state regulation has been ineffective, Congress finds federal regulation to have a certain value. ${ }^{1411}$ It may, for instance, be

138527 US 706 (1999).

139 Id at 810 (Souter dissenting).

140 The benefits that can accrue from federal regulation are familiar: It can serve a coordinating function. See, for example, the Food, Drug, and Cosmetic Act, 21 USC $\$ 301$ et seq (2000) (preventing the misuse of facilities of interstate commerce in conveying to the consumer misbranded and adulterated food). It can solve collective action problems. In the environmental protection area, federal regulation prevents a "race to the bottom" among states that would otherwise be incentivized to relax controls below socially desirable levels to attract business. See Dwyer, 60 L \& Contemp Probs at 224 (cited in note 119) ("Various failed efforts to get states to set and enforce air and water pollution standards convinced federal policy makers in the early 1970 s that the only viable solution was federal regulation."). Finally, it can break down local bar- 
needed to regulate trans-boundary problems, serve a coordinating function, solve a collective action problem, or break down local barriers to competition. We can further stipulate that, in light of the fact that Congress has included private litigation provisions in so many cooperative federalism and unitary federal statutes, it also finds enforceable, accountable regulation to have a certain value. So in those cases where Congress perceives the benefits of an enforceable federal regulation to be only worth the costs of regulating if the states are involved, Congress may choose not to regulate at all. But in those situations where Congress perceives the benefits of an enforceable federal regulation to be substantial enough to justify the costs of unitary federal regulation, Congress would instead choose to adopt the unitary model, displacing state regulators entirely. This result, in which the states are allowed to continue to regulate lesser affairs on their own, but are excluded entirely from the regulation of more critical affairs, is arguably perverse from the federalist perspective, insofar as it relegates states to a decidedly secondary role.

Perhaps some federalists would like this result. They might like a strong state sovereign immunity doctrine-one that forbids private litigation not only against state misconduct in regulated activity, which Seminole Tribe was clearly aimed at, but also against state misconduct as regulators-because it deters federal involvement in more "local" spheres. They might also like the fact that, by forcing Congress to act nationally (rather than cooperatively) in those spheres where the benefits of unitary action outweigh the costs, Congress, and not the states, will be accountable for how the scheme is carried out.

I would respond that the fact that Congress has passed these cooperative federalism statutes shows that it sees cooperative regulation as the best way to proceed in certain areas. By making Congress choose between unitary federal or state regulation, we would be forcing it to choose what is, by definition, a second-best solution. Further, there is nothing in our federalist model that envisions hermetically sealed spheres of authority between the federal government and the states. While the Framers rejected a model in

\footnotetext{
riers to competition. The 1996 Telecom Act, for instance, "enabled local competition to exist nationwide [among multiple local service providers] and erected an especially strong framework for local competition by establishing baseline rules for every company that wanted to provide telecommunications service." Deonne L. Bruning, The Telecommunications Act of 1996: The Challenge of Competition, 30 Creighton L Rev 1255, 1258 (1997). Prior to the passage of the Telecom Act, most local carriers had monopoly power, having been granted exclusive franchises in local service areas by the states. See Public Service Commission, 216 F3d at 932 (noting that, in the regime established by the Communications Act of 1934, "[i]n regulating local phone service, '[s]tates typically granted an exclusive franchise in each local service area to a local exchange carrier (LEC), which owned, among other things, the local loops . . , the switches . ., and the transport trunks"'), quoting AT\& T Corp v lowa Utilities Board, 525 US 366, 371 (1999).
} 
which the federal government acted through the states, ${ }^{141}$ as the Court has acknowledged, "under our federal system, the States possess sovereignty concurrent with that of the Federal Government." just is that there is no longer a neat dividing line between areas of federal and state power. ${ }^{143}$ Given this reality, proponents of a robust federalism should prefer to see the federal government and state governments working side by side in areas of concurrent jurisdiction, rather than see the states excluded altogether.

\section{CONCLUSION}

In College Savings, the Supreme Court cast a skeptical eye on constructive waiver of state sovereign immunity. Yet, it concluded that in certain circumstances such waiver could still be found. A careful reading of the Court's language instructs that constructive waiver of state sovereign immunity may still be found where (i) Congress offers a gift or gratuity in exchange for a state waiver of state sovereign immunity; (ii) the terms of the legislation make it clear that by accepting the gift or gratuity, the state in fact consents to suit; and (iii) acceptance of that gift or gratuity is truly voluntary. The regulation as waiver theory, which should be available for most cooperative federalism statutes, fits within the letter of these requirements. Since this exchange is voluntary, regulation as waiver does not trench on states' rights any more than preemption itself.

Absent the availability of either the constructive waiver or $E x$ Parte Young theory, private litigation under cooperative federalism statutes would be constrained in such a way that arguably undermines the effectiveness of the cooperative federalism model. Given the role cooperative federalism carves out for states to participate in regulation of local activity in an era in which the federal government has the power to regulate almost all areas of American economic life, allowing a straightforward mechanism for private litigation under these statutes, and thereby shoring up their attractiveness and effectiveness, is something that proponents of a robust federalism should support.

141 The idea of having the federal government carry out its policies through the states was proposed in an early draft of what would become the "New Jersey Plan." See Max Farrand, ed, 3 Records of the Federal Convention of 1787616 (Yale 1911) ("The laws of the United States ought, as far as may be consistent with the common interests of the Union, to be carried into execution by the judiciary and executive officers of the respective states, wherein the execution thereof is required."). This plan was rejected, see id at 313 , and the fact that a model in which the federal government operated through the states had been rejected was communicated prominently during the state ratifying conventions. See New York, 505 US at 165 (collecting examples).

142 Tafflin $v$ Levitt, 493 US 455, 458 (1990).

143 See note 137 and accompanying text. 


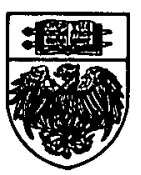

